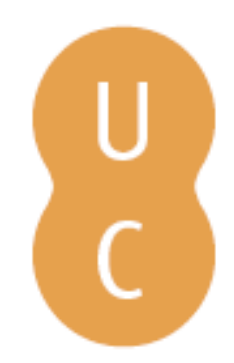

\title{
nommalina
}

O Código da Família angolano e o Livro IV do Código Civil português de 1966. Adaptação e inovação
Autor(es):
Mota, Helena
Publicado por: Imprensa da Universidade de Coimbra
URL
persistente:
URI:http://hdl.handle.net/10316.2/38886
DOI:
DOI:http://dx.doi.org/10.14195/978-989-26-1113-6_8
Accessed : $\quad$ 26-Apr-2023 08:54:23

A navegação consulta e descarregamento dos títulos inseridos nas Bibliotecas Digitais UC Digitalis, UC Pombalina e UC Impactum, pressupõem a aceitação plena e sem reservas dos Termos e Condições de Uso destas Bibliotecas Digitais, disponíveis em https://digitalis.uc.pt/pt-pt/termos.

Conforme exposto nos referidos Termos e Condições de Uso, o descarregamento de títulos de acesso restrito requer uma licença válida de autorização devendo o utilizador aceder ao(s) documento(s) a partir de um endereço de IP da instituição detentora da supramencionada licença.

Ao utilizador é apenas permitido o descarregamento para uso pessoal, pelo que o emprego do(s) título(s) descarregado(s) para outro fim, designadamente comercial, carece de autorização do respetivo autor ou editor da obra.

Na medida em que todas as obras da UC Digitalis se encontram protegidas pelo Código do Direito de Autor e Direitos Conexos e demais legislação aplicável, toda a cópia, parcial ou total, deste documento, nos casos em que é legalmente admitida, deverá conter ou fazer-se acompanhar por este aviso.

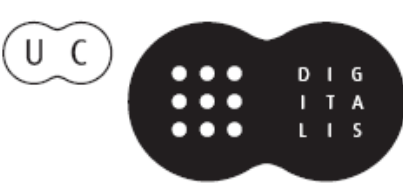




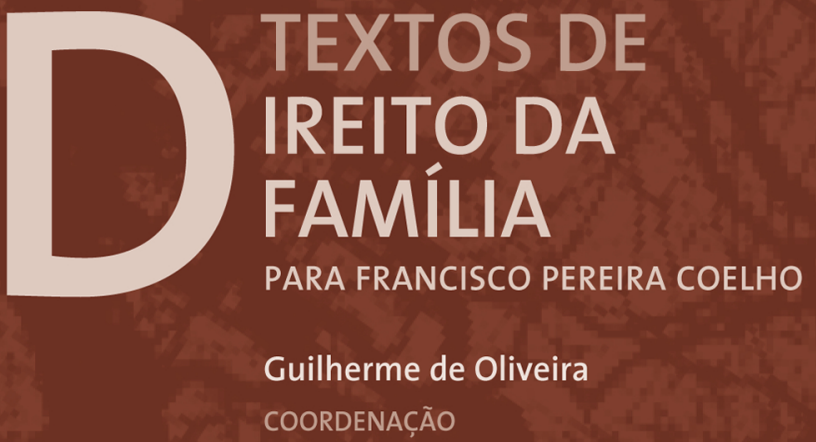




\section{O Código da família angolano e o livro iv do Código Civil PORTUGuês de 1966. \\ ADAPTAÇÃo E INOVAÇÃo.}

Helena Mota

Professora Auxiliar da Faculdade de Direito da Universidade do Porto

\section{Sumário}

1. Introdução. Razão de ordem e sequência. 2. Excurso histórico. O Direito da Família angolano antes e após a independência de Angola. 2.1 A sociedade tradicional africana e a aplicação do direito costumeiro. 2.2. A nova realidade política angolana e os valores constitucionais no âmbito do Direito da Família. 3. O Código da Família angolano e o Código Civil de 1966. 3.1. A identidade dogmática e sistemática. 3.2. A emancipação do modelo e as soluções jurídicas inovadoras. 4. As perspectivas de Reforma.

\section{Introdução. Razão de ordem e sequência}

O interesse e a importância do conhecimento e análise do Direito da Família angolano não carecem de grandes justificações no seio da comunidade jurídica portuguesa e transcendem, sem dificuldades de demonstração, o mero exercício de Direito Comparado. Os laços históricos entre os dois povos, o indelével legado linguístico e jurídico português, o aprofundamento mais recente das relações económicas entre Portugal e Angola e os fluxos migratórios, hoje 
em dois sentidos, são razões mais do que suficientes para nos determos perante o direito angolano e estudarmos a sua evolução, em especial quando, como no caso do Direito da Família, ela comporta soluções diferentes das vigentes no período colonial e se perspectivam reformas a curto espaço de tempo ${ }^{1,2}$.

Neste trabalho pretendemos analisar a principal fonte do Direito da Família angolano - o Código da Família, aprovado pela Lei n. ${ }^{\circ}$ 1/88, de 20 de Fevereiro - salientando os elementos de semelhança, em especial ao nível sistemático, com o Código Civil português e o seu Livro IV (Direito da Família), vigente em Angola, desde 1 de Janeiro de 1968 até àquela data, não sem antes passarmos por um excurso histórico que explique a transição de uma ordenação jurídica para outra e a necessária concertação entre os valores de uma sociedade tradicional africana, prenhe de costumes e ritualismos familiares, e a nova realidade política, laica, constitucional e ideologicamente comprometida, sem esquecer a superação do modelo jurídico anterior à independência.

Depois de assinalarmos os pontos de encontro entre as duas codificações no âmbito do Direito da Família, passaremos para a identificação das muitas soluções jurídicas inovadoras apresentadas pelo Código da Família angolano, que vão desde a consagração de

${ }^{1}$ A circunstância de o Direito da Família ser precisamente uma das excepções à aplicação do Código Civil português nos países africanos de língua oficial portuguesa é sublinhada por DÁRIO MOURA VICENTE, "O lugar dos sistemas jurídicos lusófonos entre as famílias jurídicas" in Separata de Estudos em homenagem ao Prof. Doutor Martim de Albuquerque, FDL, Coimbra Editora, 2010, pp. 401-429 (p. 425), que qualifica a existência de legislações autóctones mais adaptadas às necessidades particulares da vida jurídica local (vg. o Código da Família de Angola e a Lei da Família de Moçambique) como "manifestações da resistência que as matérias integradas no estatuto pessoal das pessoas singulares sempre opuseram à recepção de Direitos estrangeiros".

2 À míngua destas e de outras razões de peso sempre acrescentaríamos as muitas colaborações institucionais entre as várias Faculdades de Direito portuguesas e angolanas, in casu, entre a Faculdade de Direito da Universidade do Porto e a Faculdade de Direito da Universidade de Kimpa Vita, na província do Uíge. Foi no âmbito de tal colaboração que este texto foi desenvolvido. 
uma nova relação jurídica familiar - a união de facto - ao sistema matrimonial de casamento civil obrigatório, à limitação na escolha dos regimes de bens até a uma nova (à época) concepção de divórcio exclusivamente fundamentado na ruptura da vida conjugal, entre outras.

Finalmente, daremos conta dos "ventos de mudança" que se levantam com a ampla reforma do Direito e da Justiça angolanos, levada a cabo pela, assim designada, Comissão para a Reforma da Justiça e do Direito $^{3}$, que prevê profundas alterações também no âmbito do Direito da Família.

$\mathrm{O}$ trabalho que agora apresentamos não resulta muito enriquecido por fontes bibliográficas, pelo menos no que ao Direito da Família angolano actual diz respeito, assim como não pode contar com uma ampla divulgação da experiência jurisprudencial. Os treze anos de paz que por estes dias se comemoram em Angola são ainda curtos para permitir uma total estabilização das instituições, dos meios de divulgação do conhecimento e do trabalho de investigação científica paralisados durante 40 anos de conflito armado.

\section{Excurso histórico. O Direito da Família angolano antes e depois da independência de Angola}

Até à proclamação da independência de Angola, a 11 de Novembro de 1975, o ordenamento jurídico angolano constituía, nomeadamente no que ao Direito da Família dizia respeito, um ordenamento plurilegislativo de base pessoal. Isto é, coexistiam, na mesma ordem jurídica territorialmente unitária, diversos sistemas de normas para

3 Cfr. o sítio da Internet da Comissão de Reforma da Justiça e do Direito e os documentos aí divulgados, em especial os relativos ao Direito da Família em http:// www.crjd-angola.com/conteudos/documentos/403_20140928155422.pdf 
diferentes categorias de pessoas: o estatuto dos cidadãos e o estatuto dos indígenas ${ }^{4}$. Aos primeiros aplicavam-se as normas de direito escrito; aos segundos, o direito costumeiro.

A partir de 1961 foi franqueada a aplicação a todos os indivíduos do direito escrito, que a ele se poderiam submeter por declaração irrevogável feita mediante os serviços de registo5. O direito escrito privado vigente em Angola, no âmbito do Direito da Família, cor-

\footnotetext{
${ }^{4}$ Cfr. o art. $138^{\circ}$ da Constituição da República Portuguesa de 1933 que previa a existência nos territórios ultramarinos de estatutos especiais, a Lei Orgânica do Ultramar (Lei n. ${ }^{\circ}$ 2066, de 27 de Junho de 1954, Base V), o Estatuto dos indígenas portugueses da Guiné, Angola e Moçambique, aprovado pelo Decreto-Lei n. ${ }^{\circ} 39666$, de 20 de Maio de 1954, (mais tarde revogado pelo Decreto-Lei n. ${ }^{\circ} 43893$, de 6 de Setembro de 1961). Neste diploma o estatuto especial dos indígenas estava consagrado no art. $1^{\circ}$ "Gozam de estatuto especial...os indígenas das províncias de ... Angola..." que era classificado de base pessoal no seu § único: "o estatuto do indígena português é pessoal, devendo ser respeitado em qualquer parte do território português...". A qualificação como "indígena" resultava do art. $2^{\circ}$ "Consideram-se indígenas das referidas províncias os indivíduos de raça negra ou seus descendentes que, tendo nascido ou vivido habitualmente nelas, não possuam ainda a ilustração e os hábitos individuais e sociais pressupostos para a integral aplicação do direito público e privado dos cidadãos portugueses". Este estatuto pessoal era concretizado no art. $3^{\circ}$ "Salvo quando a lei dispuser de outra maneira, os indígenas regem-se pelos usos e costumes próprios das respectivas sociedades", limitando esta aplicação, nos termos do § único: "a contemporização com os usos e costumes indígenas é limitada pela moral, pelos ditames da humanidade e pelos interesses superiores da soberania portuguesa". É de assinalar que, no que ao Direito da Família dizia respeito, dispunha o art. $27^{\circ}$ que era permitido aos indígenas optarem pela lei comum nestas matérias, mas precisava o art. $28^{\circ}$ que "a opção...só seria aceite depois do juiz se ter certificado ... de que o requerente adoptou com carácter definitivo a conduta pressuposta para a aplicação dessas leis". Deve também sublinhar-se que, nos termos do art. $31^{\circ}, \S 1 .^{\circ}$, do diploma, estava previsto que "a mulher indígena é livre na escolha do marido, não sendo reconhecidos quaisquer costumes que se oponham a essa liberdade ou segundo os quais a mulher ou os filhos deva ser considerada pertença de parentes do marido ou pai quando este falecer".

5 Cfr. o Decreto n. ${ }^{\circ} 43897$, de 6 de Setembro de 1961, também designado por Estatuto do Direito Escrito e Estatuto dos Usos e Costumes Locais que substituiu o já citado Estatuto dos indígenas portugueses da Guiné, Angola e Moçambique. Pode ler-se no preâmbulo deste diploma que, não obstante se ter decidido a revogação dos Estatutos dos Indígenas, se mantinham válidos os estatutos de direito privado em tudo o que não contrariasse os princípios superiores da moral consagrados constitucionalmente assim como se pretendia resolver os conflitos de leis dando primazia ao direito escrito. Assim, nos termos do art. $4^{\circ}, \mathrm{c}$ ), e na falta de disposição material especial que regulasse as relações mistas, i.e, de pessoas submetidas a estatutos pessoais diferentes, ou de escolha pelas partes desse estatuto, dever-se-ia aplicar a lei escrita comum.
} 
respondia ao direito português ${ }^{6}$ que foi sofrendo, durante o século passado, as alterações conhecidas, primeiro em $1910 \mathrm{com}$ as Leis da República, depois com a Concordata de 1940 e, finalmente, com o Código Civil de 1966.

Após a independência e com a primeira Lei Constitucional que proclamava uma nova ordem de valores sociais e políticos que tangiam com o Direito da Família - separação do Estado da Igreja e das confissões religiosas (art. 7..$^{\circ}$ da Lei Constitucional de 11 de Novembro de 1975) e a igualdade de direitos e deveres dos cidadãos, independentemente de sexo (art. 18. ${ }^{\circ}$ da Lei Constitucional de 11 de Novembro de 1975) -, iniciou-se um processo legislativo caracterizado pela publicação de legislação avulsa nos vários domínios do Direito da Família, desde matéria matrimonial, filiação, adopção, entre outros, durante quase uma década até à promulgação e publicação, em 20 de Fevereiro de 1988, do Código da Família angolano aprovado pela Lei $n .^{\circ} 1 / 88$.

Do ponto de vista estritamente constitucional, só com a Lei Constitucional de 1992 (Lei n. ${ }^{\circ}$ 23/92, de 16 de Setembro) a família foi directamente considerada e protegida, nos arts. $29 .^{\circ}, 30 .^{\circ}$ e $31 .^{\circ}$, consagrando, respectivamente, o princípio da protecção pelo Estado da família fundada quer no casamento quer na união de facto, a igualdade de direitos e deveres do homem e da mulher no seio da família, a obrigação da família e do Estado em educar e proteger as crianças e os jovens, o respeito pela personalidade de todos os membros da família e, em especial, das crianças. Os mesmos princípios constam da actual Constituição da República de Angola de 2010 , designadamente dos arts. $35 .^{\circ}, 80 .^{\circ}$ e $81 .^{\circ}$.

${ }^{6}$ O Código Civil português de 1867 , aplicado às províncias ultramarinas através do Decreto de 18 de Novembro de 1869 , arts. $3 .^{\circ}$ e $8 .^{\circ}$, assim como o Código Civil português de 1966 , tornado extensível às províncias ultramarinas pela Portaria $n .^{\circ}$ 22869, de 1.1.1968. 


\subsection{A sociedade tradicional africana e a aplicação do direito costumeiro}

O papel do costume como fonte de direito e de regulação das relações sociais nas sociedades africanas é de indiscutível relevância, e Angola não é excepção.

A par de outras características como a predominância da conciliação (em vez do litígio judicializado) na resolução dos conflitos e a procura de uma solução de harmonia que sirva o todo da comunidade, em vez do reconhecimento e/ou efectivação da justiça devida a uma das partes ${ }^{7}$, é o costume, como um conjunto de tradições e práticas ancestrais assumidas numa comunidade e que devem ser respeitados por todos para garantir a paz social, a coesão do grupo e a unidade e o fortalecimento contra as adversidades e os adversários, quem mais bem caracteriza os sistemas jurídicos africanos.

O respeito pela prática costumeira faz as vezes da regra geral e abstracta e é assim fonte de direito para além de não poder ser dissociado do sagrado, assumindo simultaneamente o carácter de norma leiga e religiosa.

A importância do costume na sociedade africana, em geral, e em Angola, em particular, também não pode ser compreendida sem analisarmos a estrutura social e as dinâmicas hierárquicas que a sustentam. As sociedades tradicionais africanas são comunitárias, não valorizam o individualismo e dependem da autoridade do chefe: "a autoridade do costume coexiste em regra com dois factores:

7 Assim, DÁRIO MOURA VICENTE, "Unidade e diversidade nos actuais sistemas jurídicos africanos", in ANTÓNIO MENEZES CORDEIRO, LUÍS MENEZES LEITÃO E JANUÁRIO COSTA GOMES (orgs.), Prof. Doutor Inocência Galvão Telles: 90 anos. Homenagem da Faculdade de Direito de Lisboa., Coimbra, Almedina, 2007, pp. 317-338 (pp. 319-21), enunciando os factores de unidade entre os sistemas jurídicos africanos, a saber: relativização do papel do Direito na disciplina das relações sociais, relevo da conciliação como meio de resolução de litígios, o papel do costume como fonte de Direito tradicional e a comunhão de valores e de instituições. Cfr. no mesmo sentido, T.W.BENNETT, "Comparative law and African customary law", in MATHIAS REIMANN E REINHARD ZIMMERMANN (ORGS.), The Oxford Handbook of Comparative Law, Oxford University Press, Oxford, 2006, pp. 642-661 (pp. 650 e 657). 
a autoridade dos chefes e a autoridade dos antepassados"8. São sociedades essencialmente rurais e a propriedade é dimensionada à escala da família.

É no seio das relações familiares que a força do costume se faz sentir com mais intensidade, reflectindo também a própria organização social e económica em torno de células comunitárias como a tribo, o clã, e a família9; por isso, o casamento é uma aliança entre famílias que tem valor económico ${ }^{10}$ : assim se explica a importância do alambamento ${ }^{11}$; a mulher está subordinada ao poder do marido e do pai donde não se poder opor, sendo menor, ao noivo escolhido pelo patriarca nem aos segundos casamentos ou uniões do seu

${ }^{8}$ Assim, Maria do CARmo MEdina, Direito de Família, Lobito, Escolar Editora, 2011 , p.58.

9 A propósito deste comunitarismo que, a par da hierarquização da sociedade, pode ser classificado como um valor comum entre os povos Bantos, cfr, DÁRIO MOURA VICENTE, "Unidade e diversidade...", cit., p. 328.

10 Cfr. Maria do Carmo Medina, Direito de Família,..., cit., p. 25, e Adebayo OYEBADE, Culture and Customs of Angola", eBook Academic Collection, EBSCO, Publishing, Greenwood Pub.Group, 2007, p. 114.

$11 \mathrm{O}$ alambamento, ainda praticado em Angola, consiste numa promessa de casamento dotada de solenidades e rituais específicos segundo os quais a família do noivo entrega à família da noiva uma compensação económica: "O alambamento é o dinheiro que aquele que pretende uma rapariga para casar dá aos pais dela juntamente com alguns outros bens, como um boi, um porco, um pano ou um fato, e algumas bebidas" (in MOISÉs MBAMBI, O alambamento nos Direitos Africanos, disponível em. http://www.fd.ulisboa.pt/wp-content/uploads/2014/12/MoisesMbambi-O-ALAMBAMENTO-NOS-DIREITOS-AFRICANOS.pdf) que refere um valor de 100 dólares americanos como valor médio pago pelo alambamento. A origem da palavra é referida pelo A. como "um neologismo que os angolanos criaram para preencher a lacuna verificada na língua portuguesa para designar ovilombo (pedido de casamento) em umbundu; ovilombo vem do verbo umbundu okulomba (pedir). Quanto à natureza da figura refuta a ideia de semelhança com o dote ocidental, considerando que não é nem um preço nem um aforro para a mulher, mas antes é visto na sociedade africana como "uma prenda, um reconhecimento e gratidão, ou, e bem melhor, um prémio à noiva e seus pais, pelo seu bom comportamento e virtudes familiares". No mesmo sentido, cfr. ADEBAYO OYEBADE, Culture and Customs of Angola".., cit., pp. 116-17 e T.W.BENNETT, "Comparative law and African customary law", in MATHIAS REIMANN E REINHARD ZIMMERMANN (ORGS.), The Oxford Handbook of Comparative Law, Oxford, 2006, pp. 642-661 (p. 649). 
marido; para manter a unidade familiar e a aliança forjada pelo casamento existe o sororato e o levirato ${ }^{12}$.

A subsistência do costume como fonte de direito em Angola foi colocada em causa logo após a independência com a proclamação do Estado angolano unitário, i.e. onde não mais coexistem ordenamentos plurilegislativos nem de base territorial nem pessoal ${ }^{13}$. No entanto, é o próprio texto constitucional de 2010, no seu art. 7. ${ }^{\circ}$, quem vem dar relevância ao costume, sendo "reconhecida a validade e a força jurídica do costume que não seja contrário à Constituição nem atende contra a dignidade da pessoa humana”, sendo omisso relativamente ao costume contra legem ${ }^{14,15}$.

12 O levirato consiste na obrigação da mulher viúva casar com o irmão do falecido marido; o sororato é a obrigação do homem viúvo casar com a irmã da esposa falecida. Na lei judaica, o levirato é uma obrigação imposta ao irmão do falecido de casar com a viúva para assegurar a continuação da família. Nas sociedades africanas, por exemplo entre os Bakongo de Angola, a viúva pertence ao irmão do falecido como herança. Assim, JOÃO VICENTE MARTINS, Os Bakongo ou Tukongo do nordeste de Angola, INCM, Lisboa, 2008, p. 126 e 161.

13 Cfr. o art. $4 .^{\circ}$, n..$^{\circ}$, e), da Lei Constitucional de 1992 e o art. $8 .^{\circ}$ da Constituição de 2010. Reflectindo sobre esta visão negativa do direito costumeiro como um obstáculo à emancipação do período colonial, cfr. T.W.BENNETT, "Comparative law and African customary law"..., cit. p. 662: "Custom was all too often seen as an obstacle to the two great imperatives of the age: national unity and modernization".

${ }^{14} \mathrm{Em}$ texto anterior a 2010, ANTÓNIO BARBAS HOMEM, "Sobre as fontes do direito angolano", in ANTÓNIO MENEZES CORDEIRO, PEDRO PAIS DE VASCONCELOS E PAUla COSTA E SILVA (orgs.), Estudos em honra do Professor Doutor José de Oliveira Ascensão, I, Coimbra, Almedina, 2008, pp. 319-342 (pp. 325-6), considera que os costumes, não estando recebidos no Código Civil nem no Código da Família, não são fonte de direito, sendo apenas admitidos quando a lei assim o determinar.

15 Como veremos com mais detalhe infra em 3.2, o costume nas relações familiares teve influência na conformação do direito positivo, nomeadamente quanto à consagração da união de facto como relação jurídica familiar, à relevância do conselho de família ou à não consagração do impedimento matrimonial do parentesco no $3 .^{\circ}$ grau da linha colateral (tios/sobrinhos) por ser desde logo rejeitada pelo costume. Não nos parece relevante neste âmbito restrito de influência do costume nas soluções de direito positivo, a consagração de uma causa de validação do casamento anulável por falta de requisitos formais, tal como a prevista no art. $73 .^{\circ}, \mathrm{d}$ ), do Código da Família angolano e referida por DÁRIO MOURA VICENTE, "Unidade e diversidade...", cit., p. 324, por ser decalcada da solução do art. $1633 .^{\circ}$, n. ${ }^{\circ} 1$, d), do Código Civil português. Já relativamente ao instituto da promessa de casamento, a solução encontrada é muito diferente da configuração costumeira do alambamento, assim como não foi dada qualquer primazia à linha materna do parentesco, apesar 
Se a subsistência de facto do costume na sociedade angolana parece indesmentível, diferente será a sua aplicação coerciva pelos tribunais ou outros órgãos de aplicação do direito. É de referir, quanto a este aspecto, o art. $38 .^{\circ}$, d), da Lei n. ${ }^{\circ} 18 / 88$, de 31 de Dezembro (Lei do Sistema Unificado de Justiça), que atribui competência aos Tribunais Populares Municipais de "preparar e julgar as questões cíveis, seja qual for o seu valor, quando as partes estiverem de acordo com a aplicação exclusiva de usos e costumes não codificados, sempre que a lei o permitir", no que se infere a sua aplicação judicial e vinculativa, uma vez verificados os seus pressupostos, i.e, a aceitação voluntária pelas partes e a não contrariedade pelos mesmos dos princípios fixados na lei ${ }^{16}$.

Muito diferente será a vigência e aplicação de figuras do direito costumeiro que contrariem princípios constitucionalmente consagrados como a unidade do casamento (monogâmico) ${ }^{17,18}$, a igualdade do homem e da mulher no casamento e a não discriminação dos filhos legítimos e ilegítimos, princípios que, de resto, e como veremos, inspiram todas as novas soluções do Direito da Família ordinário o

de no direito costumeiro ser mais relevante a via matrilinear, assumindo o tio materno as funções de chefe da família (assim, MARIA Do CARMo MEDina, Código de Família anotado, Luanda, Colecção Faculdade de Direito UAN, 2. ${ }^{a}$ ed., 2005, p.23). Sobre os sistemas patrilineares e matrilineares nalgumas etnias de Angola, cfr. JOÃO VICENTE MARTINS, Os Bakongo ou Tukongo do nordeste de Angola, INCM, Lisboa, 2008, pp. 126 e 150 e ss.

16 Neste sentido, cfr. MARIA do CARMo MEdina, Direito de Família,..., cit., p. 59, e DÁrio MOURA VICENTE, "Unidade e diversidade...", cit., p. 324, considerando este A. que esta solução evidencia a supremacia do direito legislado sobre o costume nos sistemas africanos actuais, reconhecendo eficácia apenas ao costume secundum e praeter legem.

${ }^{17}$ A poligamia é comum na família tradicional africana. Cfr. ADEBAYO OYEBADE, Culture and Customs of Angola".., cit., p. 119, afirmando que na década de 80 cerca de $20 \%$ das famílias rurais eram poligâmicas.

18 Como refere MARIA Do CARMo MEDINA, Direito de Família,..., cit., p. 27, "do princípio da igualdade de direitos no direito matrimonial deriva como princípio de ordem pública, o princípio da monogamia". 
que resultará, na prática, na impossibilidade de aplicação de costume contra legem ${ }^{19}$.

\subsection{A nova realidade política angolana e os valores constitucionais}

\section{no âmbito do Direito da Família}

Como já referimos, a primeira lei constitucional angolana, de 1975, não continha normas específicas no que concerne à Família, sem prejuízo da consagração de princípios que mediatamente a condicionavam e antecipavam uma nova ordem valorativa no que tangia com as relações sociais e familiares: o princípio do Estado unitário, o princípio da igualdade e o princípio da separação do Estado e da Igreja.

De índole marcadamente ideológica e de feição marxista-leninis$\mathrm{ta}^{20}$, esta primeira Lei Constitucional serviu de âncora ${ }^{21}$ à produção legislativa que se seguiu. $O$ art. $84 .^{\circ}$ determinava a permanência em vigor das leis e regulamentos do ordenamento jurídico português vigente à data da independência enquanto não fossem revogados ou alterados e se não contrariassem o espírito daquela lei e o "processo revolucionário angolano”, sob pena de inconstitucionalidade.

Seguiu-se um período de fértil produção legislativa, em especial no Direito Público e que visava afirmar a soberania nacional e dar corpo ao projecto ideológico do $E_{s t a d o}{ }^{22}$. Mas é também no Direito

\footnotetext{
${ }^{19}$ Sem prejuízo, como adverte MARIA Do CARMo MEDINA, Direito de Família,..., cit., p. 59, "de recear que o direito costumeiro esteja a ser aplicado mesmo contra legem, lá onde existe o vazio originado pela falta de cobertura judicial para a proteç̧ão efectiva dos direitos dos cidadãos, ou nos casos em que são estes que evadindo-se da ordem jurídica legalmente estabelecida, vão acolher-se às suas regras".

20 A. MARQues Guedes et alt.., Pluralismo e Legitimação. A edificação jurídica Pós-Colonial de Angola, FDUNL, Coimbra, Almedina, 2003, p. 216: "A Lei Constitucional angolana instanciava uma variante ambiciosa e "modernizada" de um modelo que ao longo do século XX tornara "clássico": o das democracias "populares".

21 A. MARQUes GUEDES, O estudo dos sistemas jurídicos africanos, FDUNL, Coimbra, Almedina, 2004, p.56.

22 A. MARQues Guedes, idem, p. 119, referindo-se em concreto à nacionalização do ensino, da banca e das empresas e património imobiliário.
} 
da Família que se concentraram as atenções do legislador angola$n^{23}$, ao invés do que sucedeu nas demais matérias civilísticas onde continua, 40 anos depois, a vigorar o Código Civil de 1966.

Foram várias as alterações, avulsas, feitas a muitas das regras presentes no Livro IV do Código Civil de 1966 e, algumas, surgem temporalmente de modo paralelo às próprias alterações introduzidas em Portugal com a Reforma de 77 ao Código Civil, também elas comandadas pela CRP de 1976. Da dissolução dos casamentos católicos por divórcio, à proibição de referências formais à filiação ilegítima e "incógnita", da equiparação de direitos e deveres de todos os filhos e do novo enquadramento jurídico do instituto de adopção, à introdução da modalidade de divórcio por mútuo consentimento e à obrigatoriedade de celebração do casamento civil, muitas foram as disposições do Livro IV do Código Civil que resultaram revogadas expressamente ${ }^{24}$.

No entanto, apenas em 1987, com a promulgação do Código da Família e posterior publicação, em 20 de Fevereiro de 1988, aprovado pela Lei $n .^{\circ} 1 / 88$, se procedeu à sistematização completa das normas aplicáveis às relações familiares, revogando alguma da legislação avulsa entretanto publicada ou incorporando as suas soluções e revogando expressamente o Livro IV do Código Civil (art. $100^{\circ}$, c), da Lei 1/88 que aprovou o Código da Família), para além do art. $86 .^{\circ}$ (domicílio da mulher casada) e dos arts. $143 .^{\circ}, 144 .^{\circ} \mathrm{e}$ 146. ${ }^{\circ}$ (tutela) do Livro I.

23 Cfr. A. MARQues GuEdes, idem, p. 118: "As transformações jurídicas pós-coloniais que têm tido lugar ao nível do Direito angolano da Família têm sido, em muitos sentidos, mais importantes do que aquelas que têm ocorrido no plano do Direito económico e financeiro".

${ }^{24}$ Cfr., para uma listagem de toda a legislação avulsa no âmbito do Direito da Família aprovada entre 1975 e a publicação do novo Código da Família angolano, em 1988, MARIA DO CARMO MEDINA, Direito de Família,..., cit., pp. 48-49, e também HELENA LEITÃo, "O Código Civil português de 1966 nos PALOP e as tendências de reforma”, in Themis, 2008, pp. 129-161 (pp. 130-1). 
O Código da Família de 1988 condensou os novos valores constitucionais e é indelével a índole programática ${ }^{25}$ de muitas das suas normas, visível desde logo tanto no Preâmbulo quanto nos arts. 1. a $6 .^{\circ}$ que, no Título I, constituem os seus Princípios Fundamentais.

De facto, pode ler-se no Preâmbulo que "os princípios constantes do Título I da lei, contêm regras fundamentais, programáticas, que devem orientar a constituição e o desenvolvimento das relações no domínio da família, na qual os interesses pessoais de cada um dos seus membros se devem coordenar de forma harmoniosa com os interesses gerais da sociedade, com vista à criação de um novo homem angolano".

É assim um Código assumidamente não individualista que ao lado de princípios perfeitamente sintonizados com o seu tempo (igualdade entre homem e mulher (art. 3. ${ }^{\circ}$ ), protecção dos interesses da criança (art. $4 .^{\circ}$ ), livre desenvolvimento da personalidade (art. $6 .^{\circ}$ )), expressa outros, ideológica e politicamente comprometidos ${ }^{26,27}$, como a contribuição da família "na luta contra a exploração e a opressão e da fidelidade à Pátria e à Revolução" (art. 2..$^{\circ}$ e em que à família é dado um papel de contribuição para uma "nova moral social" (art. $6^{\circ}{ }^{\circ}$. Tais princípios terão ressonância nas novas soluções jurídicas, começando pela negação do casamento como contrato, passando pela abolição da validade jurídica do casamento canónico e pela consagração da união de facto como relação jurídica familiar mas que, como veremos, não impediram a manutenção, em larga medida,

25 Assim qualifica MARIA do CARMo MEdina, Código de Família anotado..., cit., p. 19, as normas do Título I do Código da Família.

26 Cfr. MARia do CARMo MEdina, Direito de Família,..., cit., p. 50: "O Código tem ainda uma função eminentemente política, no sentido da uniformização do tratamento jurídico das relações sociais, agora tratadas de forma unitária para todos os cidadãos do País".

27 O Preâmbulo usa abundantemente o jargão marxista-leninista em expressões como "novas relações de produção", "exploração do homem pelo homem", "superestrutura e relações de produção". 
da dogmática e da sistemática do Direito da Família legislado no Livro IV do Código Civil português.

\section{O Código da Família angolano e o Código Civil de 1966}

O Livro IV do Código Civil de 1966, intitulado "Direito da Família", é a principal fonte de direito da família vigente no ordenamento jurídico português, a par da Concordata entre a República Portuguesa e a Santa Sé, de 18 de Maio de 2004, o Código de Registo Civil, os Títulos III e IV da OTM e o Código Penal relativamente aos "crimes contra a família".

O Livro IV do Código Civil de 1966, que era também a vigente em Angola à data da independência, foi profundamente modificado pela Reforma de 1977 mas sofreu ainda importantes alterações nos últimos anos, nomeadamente com o novo regime jurídico do divórcio e da regulação das responsabilidades parentais, o novo conceito de casamento celebrado por duas pessoas independentemente do sexo, entre outras, sem esquecer a legislação avulsa entretanto publicada, na qual se destacam as Leis 6/2001 e 7/2001, ambas de 11 de Maio, e que regularam de forma sistemática e inovadora a vida em economia comum e a união de facto, respectivamente, a Lei da Liberdade Religiosa (Lei n. ${ }^{\circ}$ 16/2011, de 22 de Junho), a procriação medicamente assistida (Lei n. ${ }^{\circ}$ 32/2006, de 26 de Julho) e o regime jurídico do apadrinhamento civil (Lei n. ${ }^{\circ}$ 103/2009, de 11 de Setembro).

Sem prejuízo destas alterações e das muitas "pequenas revoluções" que elas comportaram, o Direito da Família português continua a estar dividido em três ramos: o direito matrimonial, o direito da filiação e o direito da tutela. No primeiro, é regulado o casamento enquanto acto (requisitos de validade substancial e formal e consequências das respectivas invalidades) e enquanto estado, comportando todos os seus efeitos pessoais e patrimoniais, assim 
como a forma da sua modificação (separação de bens e de pessoas e bens) e dissolução (morte e divórcio) e seus efeitos; o segundo tem por objecto as relações de filiação (constituição e efeitos) e ainda a filiação jurídica ou adopção; no terceiro é estudada a constituição e funcionamento da organização tutelar. O estudo das demais relações de parentesco e relações de afinidade é feito em termos introdutórios onde também surge o estudo das relações "parafamiliares", maxime a união de facto e a vida em economia comum ${ }^{28}$.

No Direito da Família angolano temos idênticas divisões: direito matrimonial, direito da filiação e demais relações de parentesco e afinidade, o direito da tutela e o direito da adopção ${ }^{29}$.

\subsection{A identidade dogmática e sistemática.}

É aceite que o Direito português, e com ele o Direito da Família, se integra na família romano-germânica, tanto por razões históricas que testemunham a forte influência do Direito Romano, subsidiário no ordenamento jurídico português até ao séc. XIX, como por ter na lei a sua principal fonte e por adoptar como método a resolução dos casos concretos a partir de regras gerais e abstractas e não de precedentes ${ }^{30}$.

Por sua vez, o Código Civil de 1966 adoptou a sistematização e classificação germânicas ${ }^{31}$ contendo, tal como o BGB, uma Parte Geral com as regras comuns a todas as categorias de relações jurídicas e os restantes quatro livros, respectivamente das Obrigações, das Coisas, da Família e das Sucessões.

${ }^{28}$ Assim, Pereira Coelho e Guilherme de Oliveira, Curso de direito da família, vol. I, $4^{\mathrm{a}}$ ed. Coimbra, Coimbra Editora, p. 35 .

29 Cfr. MARIA do CARMo Medina, Direito de Família,..., cit., p. 17.

30 Cfr. DÁrio Moura VICENTE, "O lugar dos sistemas jurídicos lusófonos..., cit., p. 425, que resume nestes termos a justificação desta pertença.

31 Assim, António Menezes Cordeiro, Tratado de direito civil português, I, Parte Geral, I, $3^{\text {a }}$ ed., Coimbra, Almedina, 2005, pp. 126 e ss. e DÁRIO MOURA VICENTE, "O lugar dos sistemas jurídicos lusófonos...", cit., p. 426. 
O Livro IV, da Família, está organizado em Títulos (disposições gerais, casamento, filiação, adopção e alimentos). Estes estão, por sua vez, divididos em capítulos onde são tratadas questões pertinentes a cada uma das matérias: a título de exemplo, o Título II (Do casamento) está subdividido em doze capítulos onde estão presentes as normas que dizem respeito, grosso modo, ao casamento como acto (capítulos I a VIII: modalidades, promessa de casamento, pressupostos, celebração, invalidades, registo) e como estado (capítulos IX e $\mathrm{X}$ : efeitos pessoais e patrimoniais) e os capítulos XI e XII sobre as modificações e a dissolução do casamento.

O Código da Família angolano seguiu uma sistemática muito idêntica. Está organizado em oito Títulos (princípios fundamentais, constituição da família, casamento, união de facto, relações entre pais e filhos, adopção, tutela e alimentos). Tomando como exemplo paralelo o direito matrimonial, verificamos que o Título III (Casamento) inclui cinco capítulos onde constam normas sobre o conceito de casamento, a promessa de casamento e a capacidade matrimonial (Cap. I), a celebração do casamento (Cap. II), os efeitos do casamento (Cap. III) a anulabilidade do casamento (Cap. IV) e a dissolução do casamento (Cap. V).

Para além desta similitude estrutural óbvia, todo o regime jurídico apresenta características essenciais que o inserem sem grande esforço na mesma família jurídica do Código Civil português. Desde logo pelas fontes e pelos métodos de aplicação do direito: a lei e a dedução de "normas previamente formuladas para uma generalidade de situações abstractamente definidas o comando que há-de governar as situações concretas da vida"32, e não o precedente judicial e a ponderação dos factos no caso concreto que indutivamente conduz à solução, como nos sistemas de Common Law.

32 DÁrio MOURA ViCEnTE, "O lugar dos sistemas jurídicos lusófonos...”, cit., p. 410. 
Assim, inexiste no Direito da Família angolano, mau grado a sua autonomização e as soluções jurídicas originais de que trataremos em pormenor no capítulo seguinte, um conceito próprio de Direito, roubando a expressão a Dário Moura Vicente ${ }^{33}$, que o exclua da família jurídica romano-germânica a que pertence o Direito da Família português.

Por outro lado, e do ponto de vista da técnica jurídica, vemos que no Código da Família angolano encontramos muitas dos caracteres que são normalmente identificados no Direito da Família português como o predomínio de normas imperativas - a maioria das regras relativas ao casamento, ao divórcio, à adopção, à tutela -, e o recurso abundante a conceitos indeterminados e cláusulas gerais ${ }^{34}-v g$. o recurso à boa fé relativamente aos efeitos do casamento anulado (art. $72 .^{\circ}$ ), a apreciação de "causa grave e duradoura" no pedido de divórcio litigioso (art. 97. ${ }^{\circ}$ ), os requisitos legais, do ponto de vista do adoptante, de "idoneidade moral e o bom comportamento social" (art. 199. $\left..^{\circ}, \mathrm{n} .{ }^{\circ} 1, \mathrm{~b}\right)$ ), entre outros -.

Relativamente à predominância das normas imperativas nos dois ordenamentos jurídicos, ela pode ser interpretada de formas diferentes: como mera revelação do interesse público atinente à organização familiar ${ }^{35}$ tal como acontece, noutros ramos de direito privado e mesmo de direito civil, com o contrato de arrendamento, o contrato de trabalho ou os contratos bancários, ou como evidência de que o Direito da Família não é direito civil e é, até, direito público ${ }^{36}$.

\footnotetext{
33 DÁRIO MOURA ViCEnTE, " O lugar dos sistemas jurídicos lusófonos..., cit., p. 429.

34 Cfr., na perspectiva do Direito da Família português, PEREIRA Coelho E GUILHERME DE OliVEIRA, Curso de direito da família...cit., pp. 143-146, e, na visão do Direito da Família angolano, MARIA Do CARMo MEDINA, Direito de Família,..., cit., pp. 55 e 66.

35 Assim, Pereira Coelho e Guilherme de Oliveira, Curso de direito da família...cit., ibidem.

36 Neste sentido, cfr. MARIA do CARMo MEdina, Direito de Família,..., cit., pp. 66-67. Para a A., o facto de o Estado intervir na defesa dos interesses da família é prova de que o Direito da Família não deve ser considerado como pertencente
} 
No entanto, regulando o Direito da Família as relações jurídicas familiares que têm como sujeitos os particulares, sem prejuízo da intervenção menor ou maior dos órgãos do Estado nos vários estádios da sua vigência, não se vê como poderia o Direito da Família, sem prejuízo da sua autonomização em relação ao Código Civil, ser outra coisa senão direito privado.

De resto, toda a construção dogmática do Direito da Família angolano assenta na relação jurídica familiar, identificando o Código da Família angolano as suas fontes no art. 7. $\mathrm{em}$ termos similares ao art. $15766^{\circ}$ do Código Civil português: parentesco, casamento e afinidade, aduzindo a união de facto e não autonomizando do parentesco a adopção.

Relativamente ao casamento, o Código da Família de Angola não o define, nos termos do art. $1577 .^{\circ}$ do CC, como contrato, preferindo uma noção mais vaga: "o casamento é a união voluntária entre um homem e uma mulher, formalizada nos termos da lei, com o objectivo de estabelecer uma plena comunhão de vida" (art. 20. ${ }^{\circ}$ ).

São conhecidas as resistências e hesitações, mesmo no seio da doutrina, quer portuguesa quer estrangeira ${ }^{37}$, quanto à classificação do casamento como contrato. O facto de o casamento ser um negócio pessoal, de as declarações de vontade terem o mesmo conteúdo, de existir uma tendencial indissolubilidade do vínculo, de haver intervenção dos órgãos do Estado, todos os argumentos se esgrimem para lhe chamar acordo, instituição, acto administrativo, negócio plurilateral, entre outros. Nenhum destes argumentos é suficientemente convincente e implica até alguma confusão entre questões de forma (constitutiva) e substância, esquece aspectos

ao direito civil, para além de defender a inconsistência da divisão bipartida entre direito público e direito privado, posição claramente tributária dos sistemas de direito socialista.

37 Para referências nos direitos estrangeiros, cfr. PEREIRA COELHO E GUILHERME DE OliveIrA, Curso de direito da família... cit., pp. 198-201, em notas. 
relevantes do seu regime como o do divórcio, a admissibilidade dos casamentos urgentes, e, em especial, todo o regime dos impedimentos, dos vícios do consentimento e faltas/divergências da vontade e respectivas sanções, maxime, a invalidade, que faz projectar a importância da declaração de vontade e da sua formação como elemento constitutivo de um negócio jurídico bilateral, i.e., de um contrato que é o casamento.

Donde, apesar de o Código da Família angolano ter preferido outra noção legal de casamento, certo é que todas as regras que referimos relativamente à exigência de capacidade matrimonial (ainda que específica relativamente às regras gerais sobre a capacidade de exercício), ao regime dos vícios e das faltas e divergências da vontade e o seu regime de anulabilidade, nos conduzem à qualificação deste acordo como um verdadeiro contrato, enquanto negócio jurídico bilateral ${ }^{38}$ integrado por duas declarações de vontade tendentes à produção e conformação ${ }^{39}$ de efeitos jurídicos, neste caso tipificados dada a sua particular índole pessoal.

38 O que, de resto é, afirmado por MARIa do CARMo MEDINa, Direito de Família,..., cit., p.63, "negócio jurídico bilateral é o acto de casamento" para acrescentar contraditoriamente a seguir: "mesmo quando intervêm duas vontades, o acto não se resolve num contrato propriamente dito, pois as regras que regulam o direito das obrigações não the são aplicáveis", afirmação com a qual não podemos concordar uma vez que, precisamente, há inúmeras regras senão das obrigações, pelo menos da Parte Geral que se aplicam, nomeadamente as que dizem respeito aos efeitos da anulabilidade, a pressupostos das figuras da invalidade, por exemplo. Aliás, no Código da Família angolano apesar de estarem previstas, no art. $\left.65^{\circ}, \mathrm{b}\right)$, como causas de anulabilidade, a falta ou vício da vontade, estas figuras não estão reguladas em matéria de casamento pelo que se deverá aplicar a regras gerais previstas nos arts. $240 .^{\circ}$ e ss. do Código Civil de 1966.

39 Como sublinha Pereira Coelho e Guilherme de Oliveira, Curso de direito da família...cit., p. 197, não se trata apenas da opção dos nubentes em casarem ou não mas também a de escolherem a pessoa do outro nubente, a de optarem entre casamento civil ou católico, de o fazerem pessoalmente ou por intermédio de procurador e de conformarem muitos aspectos do seu regime ao nível dos deveres conjugais e outros efeitos pessoais (escolha da residência da família, da orientação da vida em comum, do modo de cumprimentos do dever de assistência, etc.). 
Para além dos já referidos elementos de semelhança, muitas normas são quase literalmente decalcadas das constantes no Livro IV do Código Civil: basta uma breve leitura para nos confrontarmos com capítulos inteiros quase transcritos, como é o caso do Cap. IV ou do Cap. II.

E, no entanto, o Código da Família angolano superou em muitos casos o seu modelo e encontrou soluções diferentes, eventualmente mais talhadas à realidade da sociedade e da família angolanas. É o que veremos em seguida.

\subsection{A emancipação do modelo e as soluções jurídicas inovadoras.}

Logo no que diz respeito às fontes das relações jurídicas familiares, o art. $7 .^{\circ}$ do Código da Família altera o elenco do art. 1576. ${ }^{\circ}$ do Código Civil, indicando, por um lado, a união de facto (regulada mais adiante no Título IV), e omitindo, por outro, a referência à adopção que é integrada na relação jurídica de parentesco.

A união de facto no Direito da Família angolano tem relevo constitucional, estando prevista a protecção da família pelo Estado quer esta se funde no casamento quer em união de facto (art. 35. da Constituição de Angola de 2010).

Ao contrário do que sucedeu nos países ocidentais, em que a regulação da união de facto surgiu nos últimos anos mais por imperativos ideológicos ou de afrouxamento dos formalismos e convenções sociais e até pelo decréscimo da vivência religiosa nas sociedades urbanas ${ }^{40}$, em Angola a normatização da união de facto e a elevação à categoria de fonte, equiparada ao casamento, de relações familiares, apenas espelhou uma realidade social e cultural

40 Sobre estas razões, cfr. HELENA MOTA, "O problema normativo da família. Breve reflexão a propósito das medidas de protecção à união de facto adoptadas pela Lei n. ${ }^{\circ}$ 135/99, de 28 de Agosto", in Estudos em comemoração dos cinco anos (1995-2000) da Faculdade de Direito da Universidade do Porto, Coimbra, Coimbra Editora, 2001, pp. 535-562. 
já sedimentada e a inacessibilidade aos meios e organismos de legalização das convivências maritais ${ }^{41}$.

A união de facto no direito angolano é definida como o "estabelecimento voluntário de vida em comum entre um homem e uma mulher" (art. 112. ${ }^{\circ}$ do Código da Família) não se reconhecendo efeitos à união de pessoas do mesmo sexo. Os seus pressupostos legais, enumerados no art. 113. ${ }^{\circ}$, incluem um lapso temporal de 3 anos de coabitação consecutiva e o respeito pelos demais pressupostos para a celebração do casamento, nomeadamente a singularidade e a capacidade matrimonial. Ao invés do que se verifica noutros ordenamentos jurídicos, nomeadamente no português através da Lei 7/2001, de 11 de Maio, a união de facto legalmente reconhecida no direito angolano é equiparada totalmente ao casamento no que diz respeito aos seus efeitos pessoais e patrimoniais (art. 119. ${ }^{\circ}$ ).

Esta total equiparação da união de facto em relação ao casamento ocorre pois mediante uma formalização da relação - o reconhecimento e posterior registo -, com intervenção do órgão do Registo Civil da área de residência dos companheiros (art. 116. e 120..$^{\circ}$ e mediante o mútuo acordo dos interessados, ou apenas de um deles em caso de morte do outro ou ruptura da relação (art. 114. ${ }^{\circ}$ ), devendo neste caso haver intervenção judicial (art. 122..$^{\circ}$.

Ao lado da união de facto reconhecida legalmente e equiparada ao casamento, prevê o Código da Família angolano que sejam atendidas, para alguns efeitos legais patrimoniais e com base no instituto do enriquecimento sem causa (arts. $479 .^{\circ}$ a $482 .^{\circ}$ do Código Civil),

\footnotetext{
41 Neste sentido, cfr. MARIA do CARMo MEdina, Direito de Família,..., cit., p. 350, onde a A. refere dados estatísticos, relativos ao quinquénio 1999-2003, que mostram, para a cidade de Luanda, uma percentagem de $54 \%$ de cidadãos que vivem em união de facto, contra apenas $17 \%$ de casados, $20,3 \%$ de solteiros, 5,4\% de separados, $2,6 \%$ de viúvos e $0,7 \%$ de divorciados. A A. alerta ainda para a impossibilidade de se considerarem equivalentes o instituto da união de facto legalmente reconhecida e regulada no Código da Família e o casamento tradicional em que há regras estritas para os familiares e para o casal e em que à mulher não é reconhecido o direito a expressar o seu consentimento.
} 
assim como para a aplicação da presunção de paternidade nos termos do art. 168..$^{\circ}$ b), in fine do Código da Família), as uniões de facto que não podem ser reconhecidas por inexistência dos pressupostos legais (art. 113..$^{\circ}$.

Este regime jurídico assim sumariamente exposto revela uma singularidade em face de outras experiências jurídicas ${ }^{42}$ : não vemos aqui nem uma intervenção pontual e específica da união de facto à margem das fontes formais de relações jurídicas familiares, nem um casamento paralelo com características distintas nem sequer um casamento consensual à maneira do common law mariage.

No direito angolano, a união de facto legalmente reconhecida é, por um lado, totalmente equiparada ao casamento quanto aos seus efeitos e pressupostos legais, mutatis mutandis (exigência de prova de vida em comum por três anos e demais pressupostos legais em processo administrativo de reconhecimento $v s$. existência de uma celebração solene; anulação do reconhecimento da união de facto sem possibilidade de invocação do erro nem da omissão dos requisitos formais para a celebração do casamento; atendibilidade das demais faltas e vícios da vontade à data do pedido de reconhecimento e não da vivência em comum a cuja data, de todo o modo, retroagem os seus efeitos). No entanto, ela é livremente dissolvida por vontade unilateral de qualquer dos seus membros à excepção das situações em que o reconhecimento da união de facto se faz, a pedido de um deles, já depois de dissolvida por morte ou ruptura sendo que, neste caso, a sentença que reconhecer a posteriori a união de facto produzirá, precisamente, os mesmos efeitos da morte ou do divórcio ${ }^{43}$. Temos, assim, uma união de facto que é formalizada através

42 Cfr., entre nós, SOFIA Oliveira PAIS E ANTÓNIO FRADA DE SOUSA, "A união de Facto e as uniões registadas de pessoas do mesmo sexo - uma análise de direito material e conflitual", in ROA, 59, II, 1999, p. 695.

43 Também aqui mutatis mutandis, uma vez que alguns efeitos pessoais são próprios do casamento como a nacionalidade, a afinidade e o nome. Neste sentido, 
de um acto de vontade e de modo alternativo ao casamento, sendo difícil recusar-lhe a qualificação de negócio jurídico ${ }^{44}$, mas que, por outro lado, permite uma desvinculação unilateral e sem recurso à intervenção judicial ou administrativa na ruptura, com excepção dos casos em que o reconhecimento é pedido unilateralmente depois da morte ou ruptura. E, ao lado deste, poderemos dizer, "quase casamento" existirão as verdadeiras uniões informais que não têm de respeitar qualquer pressuposto legal, inclusivamente as uniões poligâmicas ou constituídas por quem não tem idade núbil, e que poderão, em qualquer caso, ser protegidas por aplicação das regras gerais do enriquecimento sem causa mas com efeitos aqui muito precisos, como a divisão dos bens (em compropriedade, in casu) ou o direito à morada de família ${ }^{45}$.

Outro instituto que pretendeu simultaneamente acolher uma tradição enraizada - o alambamento - mas dela se emancipar, contrariando a sua relevância social, é a promessa de casamento. Regulada no art. 22. ${ }^{\circ}$ do Código da Família, a promessa de casamento é destituída de quaisquer efeitos jurídicos e inexiste a obrigação civil de restituição de bens ou valores entregues ao outro nubente ou à

Maria do CARmo Medina, Direito de Família,..., cit., p.360. Do ponto de vista patrimonial há uma diferença sensível a ressaltar, entre o divórcio e a ruptura da união de facto, em matéria de alimentos: o art. $262 .^{\circ}$, n. ${ }^{\circ} 2$, do Código da Família limita o direito a alimentos em caso de ruptura da união de facto ao ex-companheiro que deles careça e não tenha dado causa exclusiva à ruptura, solução algo peculiar na medida em que não se compreende por que igual "sanção" não é aplicada ao cônjuge que deu causa à ruptura da vida familiar.

${ }^{44}$ Cfr. Maria do Carmo Medina, Direito de Família,..., cit., p. 354: "O mútuo acordo é condição essencial ao reconhecimento, porque têm de ser ambos a querer a conversão de uma união livre num negócio jurídico que, depois do reconhecimento, vai produzir os efeitos que produz o acto de casamento".

45 Cfr. as decisões proferidas nos Proc. 542/98 pelo Ac. da Câmara do C.A.L.F. do Tribunal Supremo de 6.11.1998, Proc. 555/99 pelo Ac. da Câmara do C.A.L.F. do Tribunal Supremo de 23.7.99, Proc. 18/01 pela Sentença do T.P. de Benguela, de 8.06.2001, pelo T.P.de Luanda na sentença da 2: ${ }^{a}$ secção da Sala de Família de 23.08.2002 (sumários transcritos em MARIA DO CARMO MEDINA, Código de Família anotado..., cit., 170 e ss.). 
sua família em caso de rompimento, sem prejuízo de, no número 2 do mesmo artigo, se prever um dever de indemnização limitado às obrigações e despesas na previsão do casamento e para as quais o nubente tenha dado o acordo, excluindo assim os lucros cessantes e quaisquer danos morais. Donde, e ao contrário do regime jurídico da promessa de casamento previsto nos arts. $15910^{\circ}$ e ss. do Código Civil, o Código da Família angolano não definir a promessa de casamento como contrato o que torna difícil a justificação deste dever de indemnizar em caso de ruptura e inexistindo até a ponderação da culpa 46 à imagem do que faz o art. $1594 .^{\circ}$. Atendendo à realidade angolana e claramente pretendendo desincentivar o costume, excluiu-se igualmente o dever de restituição dos donativos tal como está previsto no art. $1592 .^{\circ}$ e $1593 .^{\circ}$ do Código Civil, reduzindo-o à categoria de obrigação natural.

No que concerne ao direito matrimonial, o Direito da Família angolano segue um sistema de casamento civil obrigatório (art. 27. ${ }^{\circ}$ do Código da Família) não dando qualquer relevo nem eficácia civil ao casamento religioso.

A capacidade matrimonial é regulada em termos semelhantes aos consagrados no Código Civil, assentando na inexistência de impedimentos. Na previsão destes simplificou-se a sua classificação, desaparecendo a distinção entre impedimentos impedientes e dirimentes. No elenco dos impedimentos, também deixou de figurar o parentesco no $3 .^{\circ}$ grau da linha colateral, o prazo internupcial ${ }^{47}$, a tutela e a idade núbil subiu para os 18 anos, admitindo-se o casamento de menores (a partir dos 15 anos da mulher e dos 16 anos do homem) mediante autorização nos termos do art. $24 .^{\circ}$, n. $^{\circ} 2$.

46 MARIA do CARMo MEdina, Direito de Família,..., cit., p. 174, sublinha que na averiguação da causa da ruptura há que ter em conta que no Código da Família se afastaram os conceitos de culpa e inocência.

47 Considerando-se que existindo uma solução jurídica para a dupla presunção de paternidade (art. $165 .^{\circ}$ ), seria desnecessário o cumprimento do prazo. 
A afinidade em linha recta continua a constituir um impedimento à celebração do casamento mas mantém-se após a dissolução do casamento por morte ou divórcio, ao contrário do que está hoje previsto no Código Civil no art. $1585 .^{\circ}$ que limita essa permanência do vínculo à dissolução por morte. A razão para essa manutenção, mesmo nos casos de divórcio, prende-se com a obrigação de alimentos que o Código da Família estendeu aos afins na linha recta (art. $249 .^{\circ}$ ), ao contrário do que previa o Código Civil antes da Reforma de 1977. Também foi considerada a existência de relações afectivas entre os afins que seriam perturbadas pela dissolução do casamento, problema que volta hoje a ser equacionado nas sociedades ocidentais onde o número de famílias "reconstruídas" origina situações de encadeamento de vínculos familiares que se criam e desfazem sucessivamente.

Ao lado do casamento anterior não dissolvido, consagrou-se, como impedimento decorrente do princípio da monogamia, a união de facto já legalmente reconhecida.

Ao contrário do Código Civil, no Código da Família angolano entre as causas de invalidade do casamento não figura a inexistência jurídica ${ }^{48}$ mas apenas a anulabilidade e no processo preliminar de casamento omitiram-se as publicações, no mesmo sentido das alterações ao Código Civil introduzidas bem mais tarde pelo DL. n. $324 / 2007$, de 28.09 .

O regime do casamento putativo, por seu turno, é idêntico ao do Código Civil mas resultou bastante simplificado, esclarecendo-

\footnotetext{
48 Ainda assim MARIA do CARMo MEDINA, Direito de Família,..., cit., pp. 180 e ss. e 211, defende que os casamentos que não reúnam caracteres essenciais como a diversidade de sexo, as duas declarações de vontade e a intervenção do Conservador do Registo Civil (salvo nos casamentos urgentes) são inexistentes. Parece-nos difícil a admissão da figura sem a sua previsão legal. Além disso, a A. defende uma distinção entre casamentos nulos e anuláveis também sem qualquer apoio no texto da lei. Sobre as vantagens da consagração da figura da inexistência no Código civil de 66, cfr. Pereira Coelho e Guilherme De Oliveira, Curso de direito da família..., cit., pp. 300-301.
} 
-se, no n. $^{\circ} 3$, do art. $71 .^{\circ}$, que a má fé dos cônjuges nunca prejudica os efeitos putativos do casamento relativamente aos direitos dos filhos nascidos ou concebidos durante a sua vigência, tornando-se mais claro do que o homólogo regime dos arts. $1647 .^{\circ}$ e $1648 .^{\circ}$ que é omisso quanto a este ponto, regulado apenas em sede de estabelecimento de filiação, no art. $1827 .^{\circ}$. Atendendo ao regime jurídico da união de facto no direito angolano, cujo reconhecimento legal também pode ser anulado, parece-nos lacunosa a sua omissão neste regime do casamento putativo, não sendo de o incluir na remissão do art. $121 .^{\circ}$ feita aos termos gerais em que é decretada a anulação do casamento.

Do ponto de vista dos efeitos patrimoniais do casamento, verificamos também a consagração de soluções originais e igualmente condicionadas pelo costume. De facto, o Código da Família apenas prevê dois regimes-tipo: a separação de bens e a comunhão de adquiridos (regime supletivo), eliminando o regime da comunhão geral previsto no Código Civil português nos arts. $1732 .^{\circ}$ a $1734 .^{\circ}$. Este regime é incompatível com o casamento poligâmico ${ }^{49}$. Por outro lado, não foi consagrada a liberdade de convencionar regimes atípicos nem mesmo está prevista a figura da convenção antenupcial, em consonância com um modelo económico de feição socialista em que o regime da propriedade privada é desvalorizado ${ }^{50}$. Por outro lado, não há qualquer imposição de regimes de bens tal como está previsto no art. $1720 .^{\circ}$ do Código Civil.

49 Assim, Maria do CARmo Medina, Direito de Família,..., cit., p. 248, que também sublinha ser o regime da separação de bens aquele que predomina nas sociedades tradicionais africanas em virtude de a mulher não se integrar na família do marido e permanecer ligada à família de origem.

50 Neste sentido, Maria do Carmo Medina, Direito de Família,..., cit., p. 256: "(a) convenção antenupcial, que é uma figura de larga tradição nas sociedades em que predomina o regime da propriedade privada de bens. À data da elaboração do Projecto do Código de Família, não se mostrava necessário, numa sociedade que se propunha em transição para o socialismo, uma grande diversidade de regimes de bens". 
No que diz respeito ao regime de bens supletivo, a comunhão de adquiridos, não encontramos muitas diferenças no Código de Família angolano em relação ao que está estatuído nos arts. $1721 .^{\circ}$ e ss do Código Civil, sem prejuízo de uma arrumação sistemática diversa, como, por exemplo, a inclusão no elenco dos bens indicados como próprios no art. $52 .^{\circ}$ de bens tidos como incomunicáveis nos termos do art. $1733 .^{\circ}$, autonomização que se reveste de interesse no Direito da Família português dada a existência do regime-tipo da comunhão geral de bens ou mesmo da liberdade de estipulação de regimes atípicos.

Em geral, a regulação dos regimes matrimoniais no Código de Família angolano é bastante mais sucinta dando lugar a eventuais dúvidas de interpretação e aplicação: só a título de exemplo, a omissão do regime dos bens sub-rogados no lugar de bens próprios (art. $52 .^{\circ}$, b)), tal como está prevista no art. $1723 .^{\circ}$ do Código Civil, não explica as modalidades de sub-rogação (directa ou indirecta) nem a forma de ilidir, no caso da alínea c) do art. $17233^{\circ}$, a presunção de comunicabilidade dos bens prevista no art. 51. ${ }^{\circ}$, n. $^{\circ} 2^{51}$. E o mesmo acontece relativamente aos bens adquiridos em parte com dinheiro ou bens próprios e em parte com dinheiro ou bens comuns (art. 1726. ${ }^{\circ}$ do Código Civil).

Relativamente à casa de morada de família, o Código de Família prevê uma protecção menos ampla do que aquela que resulta hoje do Código Civil, no art. $1682 .^{\circ} \mathrm{A}, \mathrm{n} .^{\circ} 2$, que estende a ilegitimidade conjugal, em qualquer regime de bens, das disposições sobre o

51 Maria do CARmo Medina, Direito de Família,..., cit., p. 262, considera que face a terceiros, em caso de aquisição de bens a título oneroso com valores ou bens próprios, deve haver intervenção do outro cônjuge no acto de aquisição declarando essa proveniência, questão que é polémica, na doutrina portuguesa, que discute se tal intervenção é obrigatória quando a questão se suscitar apenas nas relações entre cônjuges. Neste sentido, cfr. PEREIRA COElHo E Guilherme De Oliveira, Curso de direito da família...cit., pp. 517-526. 
arrendamento da morada de família a todos os actos de alienação, oneração, e constituição de direitos pessoais de gozo.

No capítulo das dívidas conjugais é de assinalar a exclusão das dívidas comunicáveis contraídas no exercício do comércio (art. 1691. , d)) assim como todas aquelas cujo regime de comunicabilidade se justificaria no regime de comunhão geral de bens como as que foram contraídas, em determinados casos, antes do casamento ${ }^{52}$. Parece resultar tecnicamente incorrecta a referência, feita no art. $61 .^{\circ}$, à solidariedade da responsabilidade dos cônjuges perante as dívidas aí enumeradas, sabendo que esse regime é privativo dos regimes de comunhão de adquiridos, uma vez que, nos termos do art. $63 .^{\circ}$, n. ${ }^{\circ} 2$, no regime de separação a responsabilidade dos cônjuges é meramente conjunta.

Foi em matéria de dissolução do casamento por divórcio litigioso que o Código de Família se revelou verdadeiramente pioneiro, expurgando a culpa dos cônjuges dos fundamentos previstos no art. 97..$^{\circ}$ que estabelece apenas uma cláusula geral que permite a qualquer dos cônjuges requerer o divórcio "quando por causa grave ou duradoura esteja comprometida a comunhão de vida dos cônjuges e impossibilitada a realização dos fins sociais do casamento".

Ao contrário de outras legislações, nomeadamente o Código Civil português depois da Reforma de 77, que consagraram causas taxativas de constatação da ruptura familiar (separação de facto, ausência, alteração das faculdades mentais do outro cônjuge) ao lado das tradicionais violações culposas dos deveres conjugais, o Direito da Família angolano optou por um sistema exclusivo de divórcio-ruptura ${ }^{33}$ in-

52 Pelo menos no que diz respeito à situação visada nos arts. $1691 .^{\circ}$, n. $\left.{ }^{\circ} 1, \mathrm{c}\right)$, e n. ${ }^{\circ}$ 2. Já relativamente às dívidas para ocorrer aos encargos normais da vida familiar, prevista no art. $61 .^{\circ},{ }^{\circ}{ }^{\circ} 1,1^{a}$ parte, MARIA DO CARMO MEDINA, Direito de Família,..., cit., p. 276, entende que a comunicabilidade se pode estender a dívidas contraídas antes do casamento.

53 Maria do CARmo Medina, Direito de Família,..., cit., p. 300, entende que o conceito de divórcio acolhido no Código de Família é o do divórcio "remédio, fa- 
dicando apenas a título exemplificativo (art. 98. "designadamente") as situações da vida que justificam o pedido de divórcio unilateral. Neste sentido, foi, já em 1988, precursor do regime introduzido pela Lei n. ${ }^{\circ}$ 61/2008, de 31.10, que, no ordenamento jurídico português, ao afirmar o divórcio litigioso por ruptura do casamento manteve as causas enumeradas no art. $1781^{\circ}$ e introduziu uma cláusula residual aberta na alínea d) do mesmo preceito ${ }^{54}$.

Em coerência com um sistema de divórcio litigioso objectivo e não sancionatório do comportamento culposo dos cônjuges, foram eliminados quaisquer efeitos do divórcio determinados em função dessa posição relativa de "culpado" ou "inocente", nomeadamente benefícios recebidos em virtude do casamento (art. 80. ${ }^{\circ}$, c)), não prevendo, no entanto, em sede de regime de divórcio, a reparação

\footnotetext{
lência ou constatação de ruptura", acrescentando que "dentro deste sistema jurídico de concepção do divórcio, este pode resultar de facto ou factos imputáveis a um só cônjuge, ou de factos imputáveis a ambos, ou ainda ter surgido com o concurso ou sem o concurso da vontade dos cônjuges". São conhecidas as hesitações da doutrina e da jurisprudência portuguesas quanto ao sentido e alcance desta nova alínea d) do art. $1781 .^{\circ}$ do Código Civil que se refere a "quaisquer outros factos que, independentemente de culpa dos cônjuges, mostrem a ruptura definitiva do casamento", oscilando uns na defesa de um verdadeiro divórcio "a pedido" e outros na vinculação da decisão do juiz aos critérios de gravidade e essencialidade. Sobre esta matéria, cfr., entre outros, TOMÉ D'ALMEIDA RAMIÃO, O divórcio e questões conexas: regime jurídico atual de acordo com a lei $n .^{\circ} 61 / 2008,3^{\text {a }}$ ed., atualiz. e aumentada, Lisboa, Quid Juris, 2011, MARIA CLARA SOTTOMAYOR, MARIA TERESA FÉRIA DE ALMEIDA (COORD.), E foram felizes para sempre...?: uma análise crítica do novo regime jurídico do divórcio, Coimbra, Coimbra Editora, 2010, MARIA RITA ARANHA DA GAMA LOBO XAVIER, Recentes alterações do regime jurídico do divórcio e das responsabilidades parentais: lei $n .^{\circ}$ 61/2008, de 31 de Outubro, Coimbra, Almedina, 2009, CRISTINA M. ARAÚJO DIAS, Uma análise do novo regime jurídico do divórcio: lei $n .{ }^{\circ}$ 61/2008, de 31 de Outubro, Coimbra, Almedina, 2008.

54 No Direito da Família angolano e dada a redacção dos arts. $97 .{ }^{\circ}$ e $99 .^{\circ}$ parece inegável estarmos perante um sistema intermédio (cfr. MARIA DO CARMO MEDINA, Direito de Família,..., cit., p. 301) de aceitação do divórcio que não prescinde da avaliação do tribunal relativamente à afirmação da ruptura da vida familiar, usando aqueles diapasões de gravidade e essencialidade dos motivos apresentados, conforme decorre de várias decisões (cfr. sumários das Sentença do Tribunal do Lobito de 30.01.1994, Sentença do T.P. de Benguela (Proc. N. ${ }^{\circ}$ 18/95 e Proc. N. ${ }^{\circ} 2 / 2001$ ), T.P. do Kuanza-Sul, Proc. N. ${ }^{\circ} 13 / 87$, in MARIA DO CARMO MEdina, Código de Família anotado..., cit., pp. 162 a 165).
} 
de danos a que o actual art. 1792. ${ }^{\circ}$ faz alusão55. Por outro lado, esclareceu, quanto à data da produção dos efeitos do divórcio que poderia ser considerada a da cessação da coabitação desde que constante da sentença, tanto para efeitos patrimoniais quanto para efeitos pessoais (arts. 81. ${ }^{\circ}$ e $82 .^{\circ}$ ), redacção mais clara do que aquela que está em vigor no art. $17899^{\circ}$ do Código Civil.

No capítulo do estabelecimento da filiação, o Código de Família angolano afirmou um princípio de verdade biológica afastando-se radicalmente do paradigma do Código civil português de 1966 que se baseava na ideia de "legitimação" somente dos filhos nascidos no casamento. Essa necessidade de ruptura dogmática ditou algumas das soluções estabelecidas, nomeadamente as que resultam dos arts. $163 .^{\circ} \mathrm{e} 164 .^{\circ}$ quanto à presunção de filiação (e não de paternidade) e dos arts. $1700^{\circ}$ e ss. relativos ao estabelecimento de filiação por declaração. De facto, o Código de Família não prevê uma presunção pater is est como aquela que, já depois da Reforma de 77 , se estabelece no art. $1826 .^{\circ}$ do Código Civil, mas antes uma presunção de filiação, isto é, de maternidade e paternidade que resulta do casamento. Esta presunção, e ao contrário do art. 1826. ${ }^{\circ}$ do Código Civil, apenas funcionará se o filho nascer $e$ for concebido na constância do casamento, sendo por isso necessário, em relação às hipóteses de casamentos posteriores à concepção ou nascimento, uma declaração dos pais. Este sistema revela-se assim mais complexo e eventualmente menos protector dos interesses do filho, pelo menos em comparação com aquele que resulta, em situações paralelas, dos arts. $1828 .^{\circ}, 1829 .^{\circ}, 1830 .^{\circ}$ e $1831 .^{\circ}$ do Código Civil, e resultou aparentemente da necessidade de afirmar um princípio de

55 É de realçar, no entanto, que o regime de atribuição da residência familiar e da atribuição de alimentos ao ex-cônjuge leva em consideração as causas do divórcio (cfr. arts. $110 .^{\circ}$ e $111 .^{\circ}$ ). Neste sentido, a culpa dos cônjuges pode ser avaliada (cfr. decisão proferida no Proc. 523, Ac. da Câmara do C.A.L.F. do T.S. de 24.07.1998 cujo sumário se pode ler em MARIA do CARMO MEdina, Código de Família anotado..., cit. p. 160). 
igualdade entre os progenitores e de algum preconceito quanto ao próprio princípio de estabelecimento de paternidade por presunção 56 reduzindo o seu alcance.

No Código de Família angolano desapareceu igualmente a figura da perfilhação, substituída pela declaração de nascimento ${ }^{57}$ apesar de resultar algo obscura a afirmação, através do art. $173 .^{\circ}$, da natureza "pessoal e voluntária e irrevogável" desta declaração e a possibilidade de anulação com base no erro ou coação ou incapacidade (art. 190..$^{\circ}$.

O estabelecimento da paternidade por presunção pode também resultar, nos termos do art. $168 .^{\circ}$, da união de facto ainda que não legalmente reconhecida, o que não sucede, ainda hoje no direito português. Já muito limitativo e contraditório com o princípio da verdade biológica nos parece a limitação, consignada no art. $192 .^{\circ}$, de impugnação de paternidade presumida do marido da mãe quando está estabelecida a posse de estado em relação ao casal assim como a limitação dos meios de prova nas acções de filiação (art. 196. ${ }^{\circ}$ ), especialmente não auxiliando a prova na acção proposta pelo filho, através de presunções judicias, como o faz o art. $1871 .^{\circ}$ do CC.

\footnotetext{
56 Parece-nos resultar clara esta ideia do comentário de MARIA DO CARMO MEDINA, Direito de Família,..., cit., pp. 111 e ss., "a lei faz derivar dele (casamento), em relação ao marido e mulher, simultaneamente, o estabelecimento da filiação no que toca aos filhos nascidos e concebidos na constância do casamento". Relativamente aos filhos concebidos ou nascidos antes do casamento, afirma (p.113): "qualquer destas situações é hoje muito frequente...os filhos concebidos ou nascidos antes do casamento estavam, segundo o critério do Código Civil, na situação de filhos ilegítimos. O casamento dos pais operava a legitimação dos filhos. ...esta disposição (art. $164 .^{\circ}$ ) já não tem em vista conferir aos filhos concebidos ou nascidos antes do casamento o estatuto de filhos legítimos que não tem hoje acolhimento legal".

57 Assim, MARIa do CARMo MEdina, Direito de Família,..., cit., p.101: "O Código de Família afastou desta forma o sistema segundo o qual a filiação se estabelece por reconhecimento do progenitor...no Código Civil anterior este acto era designado por "perfilhação".
} 


\section{As perspectivas de Reforma}

Vinte e sete anos volvidos sobre a entrada em vigor do Código de Família angolano, sentiu-se necessidade de encetar uma reforma que depurasse algumas das dificuldades na interpretação e aplicação das suas normas, colmatasse lacunas e que o actualizasse em face de uma nova realidade social, política, económica e constitucional. Neste capítulo faremos eco de algumas das propostas mais significativas apresentadas no seio da Comissão para a Reforma da Justiça e do Direito ${ }^{58}$, tentando perceber as suas motivações e o seu significado.

A reforma proposta é de "tipo médio", ou seja, ao invés de introduzir alterações meramente pontuais ou, de forma mais ambiciosa, elaborar um novo Código da Família eventualmente inserindo-o no Código Civil, optou-se por reformular o Código existente "compatibilizando as normas jurídico-familiares com a Constituição, recodificando alguma legislação avulsa pertinente ao Direito da Família e actualizar as soluções vigentes".

Em matéria de Direito Matrimonial, abandona-se o sistema de casamento civil obrigatório e são consagradas "três modalidades de casamento - o civil, o tradicional e o religioso - bem como de uma série de normas visando a sua articulação que produzirão efeitos civis em consonância com os arts. $7 .^{\circ}$ e $35^{\circ}$, n. ${ }^{\circ}$ s 2 e 4 , ambos da Constituição". A previsão constitucional da relevância jurídica do costume teve aqui o seu papel, assim como a constatação dos dados sociais que não esconderam a adesão a outros modelos de casamento tradicionais e religiosos 59 . A invocação do art. $35 .^{\circ}$, n. $^{\circ} 4$, da CRA, parece implicar um sistema de casamento civil facultativo na primeira

\footnotetext{
58 Seguiremos de perto neste capítulo o documento disponibilizado no sítio da internet da Comissão de Reforma da Justiça e do Direito (www.crjd-angola.com) em http://www.crjd-angola.com/conteudos/documentos/403_20140928155422.pdf .

59 Cfr. ADEBAYO OYEBADE, Culture and Customs of Angola”...cit., p. 115.
} 
modalidade ${ }^{60} \mathrm{o}$ que representará menos a consagração de diferentes modalidades de casamento e mais a mera alternativa por várias formas de celebração do casamento cujo regime, requisitos e jurisdição permanecerão sob o império da lei civil e dos tribunais do Estado.

No que diz respeito à promessa de casamento, "estender o direito à indemnização, quando a ele haja lugar, aos parentes que tenham actuado em nome e representação de um dos nubentes e incorrido em despesas na provisão do casamento". Esta solução parece ir ao encontro não só à prática costumeira mas também acaba por aderir à solução consagrada já no Código Civil, no art. 1594. ${ }^{\circ}$.

Relativamente à idade núbil, ela descerá aos "16 anos como limite mínimo excepcional para a celebração do casamento em relação a ambos os sexos, obedecendo ao princípio da igualdade", solução também mais próxima da consagrada no Código Civil.

No que concerne aos efeitos do casamento, a Reforma pretende "precisar melhor as normas relativas à administração dos bens do casal, acrescentando outros bens aos já existentes e que podem ser administrados por um dos nubentes, bem como os seus poderes de alienação de bens" assim como "consagrar a liberdade de celebração de convenções matrimoniais, podendo ser antenupciais ou pós-nupciais, consoante celebradas antes ou depois do casamento, bem como a previsão de uma série de normas visando a efectivação dessa liberdade". Estas últimas alterações espelham bem a actual realidade política e económica de Angola, superado o modelo marxista-leninista, e do novo enquadramento constitucional, para além de fazerem eco das soluções mais recentes doutros ordenamentos jurídicos relativamente ao princípio da imutabilidade dos regimes de bens ${ }^{61}$. Nesta mesma linha de "liberalização" e aprofundamento da

60 Sobre os sistemas matrimoniais, cfr. PEREIRA COELHO E GUILHERME DE OliveIRA, Curso de direito da família...cit., pp. 174-180.

${ }^{61}$ Sobre este princípio da imutabilidade ainda consagrado no Direito da Família português no art. $1714 .^{\circ}$ e das críticas à sua manutenção, com dados do direito 
autonomia negocial dos cônjuges "acrescentar-se mais dois regimes de bens aos já existentes, passando, assim, o ordenamento jurídico familiar a contar com os regimes de comunhão de adquiridos e separação de bens já em vigor, bem como com o da comunhão geral de bens e o da participação final nos adquiridos”. Também em sede de efeitos patrimoniais do casamento há a recuperação da "obrigatoriedade da adopção do regime de separação de bens, sempre que o casamento seja celebrado sem a observância do processo preliminar ou por pessoas com 60 anos de idade", tal como estava previsto no art. $1720 .^{\circ}$ do Código Civil.

Fazendo eco a algumas dificuldades que já aqui apontámos e no que respeita "à matéria das invalidades do casamento, além do actual regime da anulabilidade, prevê-se consagrar também, de forma expressa, a inexistência e a nulidade do casamento".

Em sede de divórcio e provando a modernidade do sistema vigente não há a previsão de grandes alterações à excepção da consagração da "liberdade de se requerer o divórcio, eliminando-se o período de moratória legal" o que também está previsto hoje no art. $1775 .^{\circ}$ do Código Civil.

Em matéria de união de facto, e para além da diminuição do período mínimo de convivência para dois anos ou um ano, no caso em que haja filhos da união de facto, também se acautelou a união de facto que não pode ser reconhecida, maxime a poligâmica, impondo-se o regime da separação de bens e estabelecendo regras precisas visando proteger a família anterior surgida de casamento ou união de facto reconhecida.

Relativamente à ruptura da união de facto, "entendeu-se consagrar, por remissão, o regime da sua dissolução, dando-se, assim,

estrangeiro, cfr. PEReira Coelho e Guilherme De Oliveira, Curso de direito da família..., cit., pp. 489 a 500 e HELENA MOTA, Os efeitos patrimoniais do casamento em direito internacional privado. Em especial, o regime matrimonial primário, Coimbra, Coimbra Editora, 2012. 
resposta a uma lacuna actual". Assim se entendendo parece-nos que pelo menos a união de facto legalmente reconhecida se aproximará mais de um common law marriage que não prescinde da intervenção dos órgãos estatais para a sua dissolução.

No tangente à filiação, a reforma pretende "esclarecer quando é que se deve considerar um filho como tendo sido concebido na constância do casamento; estabelecer que o Ministério Público pode interpor acção de estabelecimento judicial da filiação, durante toda a menoridade, ao contrário do regime actual onde tal faculdade apenas pode ser exercida durante os 3 primeiros anos de vida do menor e introduzir uma norma relativa à procriação por inseminação artificial, homóloga ou heteróloga". Sem prejuízo destas alterações parece-nos, como já referimos, que outros aspectos relativos ao regime do estabelecimento da filiação poderiam ser repensados.

Na matéria da autoridade paternal, a Reforma pretende claramente sintonizar o Código de Família com as orientações mais recentes nesta matéria, substituindo a designação do instituto para "responsabilidade parental" e incluindo o "sistema de guarda conjunta do filho, nos casos de exercício em separado da autoridade paternal, objectivando-se proporcionar ao menor um ambiente familiar que mais se assemelha à modalidade ideal, isto é, a do exercício conjunto da autoridade paternal".

Obviamente que uma análise mais completa desta reforma só poderá ser feita mediante o texto final que for aprovado mas parece clara, neste momento, a manutenção da identidade sistemática e dogmática entre o Código de Família e o Código Civil português, eventualmente até mais aprofundada pois se, em muitos casos, as novas soluções materiais visam temperar algumas intenções de ruptura com a legislação pretérita que não se revelaram, afinal, assimiladas pela realidade social angolana (falamos, por exemplo, do sistema matrimonial de casamento civil obrigatório ou a irrelevância jurídica quase total da promessa de casamento ou mesmo da impossibilidade 
de celebração de convenções antenupciais), por outro, a própria modernização do Direito da Família português determinou um encontro e uma sintonia de soluções que é muito interessante de verificar e que deve representar mais um passo de aproximação entre dois povos cujo passado comum não pode ser apagado.

Porto, 1 de Abril de 2015 
(Página deixada propositadamente em branco) 